\title{
TINDAK PIDANA PELAKU EKSPLOITASI SEKSUAL PADA ANAK MENURUT HUKUM ISLAM
}

\author{
Ariyadi, S.H.I., M.H \\ Universitas Muhammadiyah Palangkaraya \\ Email: ariyadialbanjari@gmail.com
}

\begin{abstract}
Abstrak
Penelitian ini dilatar belakangi oleh pertanyaan bagaimana ketentuan hukum tindak pidana eksploitasi seksual pada anak menurut hukum Islam? Penelitian ini bertujuan untuk mengetahui ketentuan hukum tindak pidana eksploitasi seksual pada anak menurut hukum Islam yang meliputi bentuk, unsur dan sanksi hukumnya.

Penelitian ini digunakan metode penelitian hukum normatif, yaitu dengan mengkaji beberapa bahan hukum, baik bahan hukum primer, sekunder maupun tersier. Teknik pengumpulan bahan hukum dilakukan dengan survey kepustakaan dan studi literatur. Bahan hukum yang diperoleh kemudian diolah dengan teknik editing dan interpretasi data. Kemudian untuk memperoleh hasilnya dilakukan analisis komparatif yang bersifat deskriptif, di mana seluruh bahan yang diperoleh diuraikan terlebih dahulu berdasarkan sistematika yang telah penulis tetapkan, kemudian membandingkan bahan-bahan tersebut untuk merumuskan suatu kesimpulan.

Melalui analisis hukum Islam, penelitian ini menghasilkan temuan: Tindak pidana pelaku eksploitasi seksual pada anak menurut hukum Islam tidak diatur secara khusus, dalam Islam hanya mengatur tentang larangan melacurkan budak-budak perempuan serta larangan mengambil hasil dari tindakan pelacuran tersebut.
\end{abstract}

\section{A. PENDAHULUAN}

Karunia Tuhan Yang Maha Esa merupakan amanah yakni anak, yang senantiasa harus dijaga karena dalam dirinya melekat harkat, martabat dan hakhak sebagai manusia seutuhnya. Anak merupakan tunas, potensi dan generasi muda penerus cita-cita perjuangan bangsa, memiliki peran strategis dan mempunyai cita-cita dan sifat khusus yang menjamin kelangsungan eksistensi bangsa dan negara pada masa depan. ${ }^{1}$ Sebagai amanah Allah SWT yang dititipkan kepada orang tua, anak pada dasarnya harus memperoleh

\footnotetext{
${ }^{1}$ Republik Indonesia, Undang-Undang R.I. Nomor 23 Tahun 2002 Tentang Perlindungan Anak, (Bandung: Citra Umbara, 2012), h. 75.
}

perlindungan serta perhatian yang cukup dari kedua orang tua, karena kepribadiannya ketika dewasa akan sangat bergantung kepada pengajaran masa kecilnya terutama yang diperoleh dari kedua orang tua dan keluarganya. ${ }^{2}$

Dalam pandangan Islam, para orang tua pada hakikatnya sudah terbebani tanggungjawab terhadap anak-anaknya sejak mereka masih belum dilahirkan, bahwa membangun sebuah keluarga harus selalu tegak berpijak di atas fondasi agama, akhlak, pengetahuan tentang tugas

\footnotetext{
${ }^{2}$ Juwariyah, Dasar-Dasar Pendidikan Anak Dalam Al-Qur'an, (Yogyakarta: Teras, 2010), h. 67.
} 
dan peran keluarga. ${ }^{3}$ Islam memberikan hak-hak pada anak seperti yang terdapat dalam Al-Qur'an, yaitu di antaranya hak untuk mendapatkan pendidikan, nafkah, perlindungan dan pemeliharaan, seperti yang terhadap dalam Al-Qur'an: (QS. AtTahrim/66:6) ${ }^{4}$

Perlindungan anak semestinya berpedoman pada upaya yang menjadikan anak sebagai manusia yang patut mendapat perhatian yang baik. Perlindungan anak merupakan satu usaha yang mengadakan kondisi di mana setiap anak dapat melaksanakan hak dan kewajibannya. ${ }^{5}$ Menurut pandangan Islam, tindakan menjerumuskan seseorang dalam prostitusi seksual merupakan bentuk kezaliman, karena merupakan pekerjaan yang menurut agama Islam dilarang keras untuk mengerjakannya. Karena dianggap mengandung bahaya bagi masyarakat, baik terhadap aqidah, akhlaknya, harga dirinya dan sendi-sendi peradaban masyarakat, khususnya bagi keselamatan dan kehormatan. $^{6}$ Tindakan tersebut merupakan sesuatu yang diharamkan dan termasuk dosa besar. Ada dua hal mengapa

\footnotetext{
${ }^{3}$ Hamdan Rajih, Cerdas Akal Cerdas Hati, (Yogyakarta: Diva Press, 2008), h. 34.

${ }^{4}$ Departemen Agama Republik Indonesia, Al-Qur'an Dan Terjemahnya, (Jakarta: CV. Toha Putra Semarang, 1989), h. 951.

${ }^{5}$ Majda El Muhtaj, Dimensi Dimensi HAM Mengurai Hak Ekonomi dan Budaya, (Jakarta: Rajawali Pers, 2009), h 228.

${ }^{6}$ Yusuf Qardhawi, Halal wal Haram fil Islam, (Bandung: Jabal, 2009), h. 141.
}

tindakan tersebut diharamkan. Pertama, karena pada dasarnya memperdagangkan manusia itu haram. Kedua, karena anak berada pada usia perlindungan yang belum memiliki kedewasaan, sehingga mempunyai kerentanan sangat tinggi untuk dieksploitasi di luar kepentingan dirinya. ${ }^{7}$ Nabi Muhammad SAW bersabda:

$$
\text { Artinya: "Dari }
$$

Dzar, "Rasulullah SAW bersabda dalam hadis Qudsi yang diriwayatkan dari Allah, "Wahai hamba-Ku, sesungguhnya Aku haramkan kezaliman terhadap diri-Ku dan terhadap hamba-Ku, maka janganlah kamu saling menzalimi satu sama lain".(HR. Muslim). ${ }^{8}$

Menurut hukum pidana Islam tindakan eksploitasi seksual dapat dikategorikan dalam bentuk jarimah yang berkaitan dengan kejahatan kehormatan dan kerusakan akhlak. Jarimah mengandung arti perbuatan buruk, jelek atau dosa. Jarimah biasa dipakai sebagai perbuatan dosa, bentuk, macam atau sifat dari perbuatan dosa tersebut. Misalnya pencurian, pembunuhan, perkosaan atau perbuatan yang berkaitan dengan politik dan sebagainya. Jarimah identik dengan pengertian yang disebut dalam hukum positif sebagai tindak pidana atau pelanggaran. Dalam hukum positif jarimah diistilahkan dengan delik atau tindak

\footnotetext{
${ }^{7}$ Djaenab, Perlindungan Anak Perspektif Figh dan Perundang-undangan, dalam jurnal AlRisalah, volume 10 (2010), h. 6.

${ }^{8}$ Imam An-Nawawi, Syarah Shahih Muslim, (Jakarta: Darus Sunnah, 2011), h. 657.
} 
pidana. ${ }^{9}$ Berdasarkan uraian di atas, terdapat permasalahan yang menarik untuk diteliti lebih dalam tentang masalah eksploitasi seksual pada anak. Anak yang seharusnya mendapatkan perlindungan yang layak dari segala macam ancaman yang merusak masa depannya, justru terjerumus kedalam dunia prostitusi. Oleh karena itu, peneliti sangat tertarik dan merasa perlu mengkaji lebih dalam mengenai tindak pidana pelaku eksploitasi seksual pada anak berdasarkan tinjauan dua sistim hukum yakni hukum Islam. Berdasarkan latar belakang yang telah dipaparkan di atas, permasalahan yang akan diteliti dalam penelitian ini adalah: Bagaimana ketentuan hukum tindak pidana pelaku eksploitasi seksual pada anak menurut hukum Islam dan hukum positif?

\section{B. Tindak Pidana Menurut Hukum}

\section{Islam}

Perbuatan manusia yang dinilai sebagai pelanggaran atau kejahatan kepada sesamanya, baik pelanggaran atau kejahatan tersebut secara fisik atau nonfisik, seperti membunuh, menuduh atau memfitnah maupun kejahatan terhadap harta benda dan lainnya, dibahas dalam fiqih jinayah (hukum pidana

\footnotetext{
${ }^{9}$ Rahmat Hakim, Hukum Pidana Islam:Fiqh Jinayah, (Bandung: Pustaka Setia, 2009), h. 14-15.
}

Islam). ${ }^{10}$ Dalam fiqih jinayah (hukum pidana Islam), ada dua istilah penting yang terlebih dulu harus dipahami yaitu istilah jinayah dan Jarimah . Kedua istilah ini secara etimologis mempunyai arti dan arah yang sama. Jinayah menurut bahasa merupakan nama bagi suatu perbuatan jelek seseorang. Adapun menurut istilah adalah nama bagi suatu perbuatan yang diharamkan syara', baik perbuatan tersebut mengenai jiwa, harta, benda, maupun selain jiwa dan harta benda. ${ }^{11}$

Ada lima kejahatan yang dikenai hukuman tertentu dari syara', yaitu:

1) Kejahatan atas badan, jiwa, dan anggota badan

2) Kejahatan kelamin, yaitu yang disebut zina pelacur

3) Kejahatan atas harta

4) Kejahatan atas kehormatan

5) Kejahatan berupa pelanggaran dengan membolehkan makanan dan minuman yang diharamkan oleh syara, ${ }^{12}$

Dengan demikian, pengertian jinayah merupakan perbuatan yang diharamkan. Perbuatan yang diharamkan meliputi tindakan yang dilarang atau dicegah oleh Syara' (Hukum Islam). Apabila dilakukan perbuatan tersebut

${ }^{10}$ Rahmat Hakim, Hukum Pidana Islam, (Bandung: Pustaka Setia, 2000), h. 11.

${ }^{11}$ Ibid., h. 12. Mujtahid. 
mempunyai konsekuensi membahayakan agama, jiwa, akal, kehormatan, dan harta benda.

Istilah berikutnya yaitu Jarimah (tindak pidana), pada dasarnya kata Jarimah mengandung arti perbuatan buruk, jelek, atau dosa. Adapun pengertian Jarimah sebagai berikut:

Jarimah (tindak kriminal) adalah semua tindakan yang diharamkan oleh syariat. Allah ta'ala mencegah terJadinya tindak kriminal dengan menjatuhkan hudud atau ta'zir kepada pelakunya. ${ }^{13}$

Abdul Qadir 'Audah menyatakan pengertian jarimah yaitu:

Jarimah adalah melakukan perbuatan yang diharamkan yang apabila melakukannya mengakibatkan ancaman sanksi hukum tertentu, atau tidak melakukan perbuatan yang dilarang, yang diancam sanksi hukum tertentu apabila tidak melakukannya atau dengan kata lain, melakukan atau meninggalkan (perbuatan) yang keharamannya telah ditetapkan oleh syariat dan adanya ancaman hukuman tertentu. ${ }^{14}$

Jarimah identik dengan pengertian yang disebut dalam hukum positif sebagai tindak pidana atau pelanggaran. Maksudnya adalah satuan atau sifat dari suatu pelanggaran hukum. Dalam hukum positif contoh Jarimah seperti Jarimah pencurian, Jarimah pembunuhan diistilahkan dengan tindak pidana pencurian, tindak pidana pembunuhan, dan

\footnotetext{
${ }^{13}$ Musthofa Hasan, Hukum Pidana Islam:
} Fiqh Jinayah, (Bandung: CV Pustaka Setia, 2013), h. 15 .

${ }^{14}$ Musthofa Hasan, Hukum Pidana Islam: Fiqih Jinayah, h. 15 sebagainya. Jarimah diistilahkan dengan delik atau tindak pidana. ${ }^{15}$ Untuk dapat dikatergorikan sebagai suatu Jarimah, suatu perbuatan harus memiliki beberapa unsur, unsur-unsur tersebut yaitu:

a. Nash yang melarang perbuatan dan mengancamkan hukuman terhadapnya, unsur ini disebut unsur formil (rukun syar'i)

b. Adanya tingkah laku Jarimah , adanya perbuatan yang melawan hukum, unsur ini disebut unsur materil (rukun maddi)

c. Pembuat adalah orang mukallaf, yaitu orang yang dapat dimintai pertanggungjawabannya terhadap Jarimah yang diperbuatnya, unsur ini disebut unsur moril (rukun adabi). ${ }^{16}$

Jarimah mengandung arti perbuatan buruk, jelek atau dosa. Jarimah biasa dipakai sebagai perbuatan dosa, bentuk, macam atau sifat dari perbuatan dosa tersebut. Adapun bentuk-bentuk jarimah terbagi kedalam tiga bagian berdasarkan berat dan ringannya hukuman dan sebagaimana ditegaskan atau tidaknya dalam Al-Qur'an dan hadits, yaitu:

\section{a. Jarimah hudud}

\footnotetext{
${ }^{15}$ Ibid., h. 20.

16 Ahmad Hanafi, Asas-asas Hukum
} Pidana Islam,(Jakarta: Bulan Bintang, 1993), h.6. 
Jarimah hudud adalah suatu jarimah yang bentuknya telah ditentukan syara sehingga terbatas jumlahnya. Selain ditentukan bentuknya juga ditentukan hukumannya secara jelas, baik melalui AlQur'an maupun As-Sunnah. Jarimah ini termasuk dalam jarimah yang menjadi hak Allah.

Adapun jarimah hudud terbagi ke dalam beberapa bagian, yaitu: zina, qadzaf (tuduhan palsu zina), sariqah (pencurian), minum khamr, hirabah (pembegalan, perampokan, gangguan keamanan), rid\}ah (murtad) dan al-baghyu (pemberontakan). ${ }^{17}$

Jarimah -jarimah yang menjadi hak Allah, pada prinsipnya adalah jarimah yang menyangkut masyarakat banyak, yaitu untuk memelihara kepentingan, ketentraman, dan keamanan masyarakat.

\section{b. Jarimah qishash/diyat}

Jarimah ini juga telah ditentukan jenisnya maupun besar hukumannya. Jarimah inipun terbatas jumlahnya dan hukumannyapun tidak mengenal batas tertinggi maupun terendah karena hukuman untuk jarimah ini hanya satu untuk setiap jarimah .

Qishash juga merupakan hukuman pokok bagi perbuatan pidana dengan objek (sasaran) jiwa atau anggota badan yang dilakukan dengan sengaja, seperti

\footnotetext{
${ }^{17}$ Ibid., h. 7.
}

membunuh, melukai, menghilangkan anggota badan dengan sengaja. Jarimah qishash diyat ini terbagi kedalam lima bagian, yaitu: pembunuhan sengaja, pembunuhan seperti sengaja, pembunuhan tidak sengaja, penganiayaan sengaja, dan penganiayaan tidak sengaja. ${ }^{18}$

\section{c. Jarimah ta'zir}

Ta'zir menurut bahasa artinya atta'dib, yaitu memberi pengajaran. Dalam fiqih jinayah, ta'zir merupakan bentuk jarimah yang sanksi hukumnya ditentukan penguasa. Jadi, jarimah ini sangat berbeda dengan jarimah hudud dan qishash diyat yang macam dan bentuk hukumannya telah ditentukan oleh syara'. ${ }^{19}$ Hukuman ta'zir dijatuhkan dengan mempertimbangkan berat ringannya tindak pidana, situasi dan kondisi masyarakat, serta tuntunan kepentingan umum. Hal ini dapat dikatakan bahwa hukuman ta'zir diterapkan tidak secara definitif, melainkan melihat situasi dan kondisi, dan bagaimana perbuatan jarimah terjadi, kapan waktunya, siapa korbannya, dan sanksi yang pantas dikenakan demi menjamin ketentraman dan kemashlahatan umat. $^{20}$ Hukum pidana Islam, sebagai realisasi dari hukum Islam itu sendiri, menerapkan hukuman dengan tujuan untuk

\footnotetext{
${ }^{18}$ Ibid., h.8.

19 Musthofa Hasan dan Beni Ahmad Saebani, Hukum Pidana Islam: Fiqih Jinayah, h.

20 Makhsrus Munajat, Hukum Pidana
} 75 . Islam di Indonesia, (Yogyakarta: Teras, 2009), h. 4. 
menciptakan ketentraman individu dan masyarakat serta mencegah perbuatanperbuatan yang bisa menimbulkan kerugian terhadap masyarakat, baik berkenaan dengan jiwa, harta maupun kehormatan.

Dengan demikian, tujuan hukum pidana Islam menurut Abdul Qadir Audah, adalah melayani kebutuhan masyarakat dari segi keamanan dan terbasminya kejahatan, menjamin terpenuhinya hak-hak pribadi dan meratakan keadilan sosial, serta menimbulkan ketenangan, kedamaian dan ketentraman di antara setiap individu dan anggota masyarakat. ${ }^{21}$ Beliau menjelaskan dalam kitabnya Al-Tasyri' $A l$ Jinai Al-Islami: Muqaranan bi Al-Qanun Al-Wad'i, yaitu:
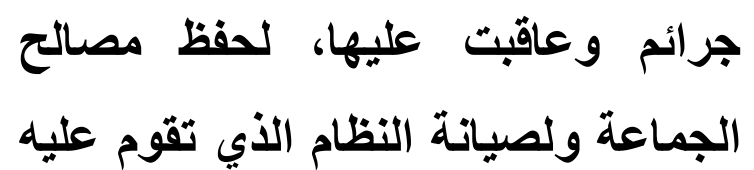

الجماعة، ولضمان بقاء الجماعة قوية متضامنة متخلقة بالأخلاق الفاضلة، والله الأي شرع هذه الأحكام وأمر بها لا تضره معصية عاص ولو عصاه أهل الأرض جميعاً، ولا تنفعه طاعة مطيع ولو أطاعه أهل الأرض جميعاً، ولكنه كتب على نفسه الرحمة لعباده، ولم يرسل الرسل إلا رحمة للعالمين، لاستثقاذهم من لرن

${ }^{21}$ Musthofa Hasan , Hukum Pidana Islam: Fiqh Jinayah, h. 27

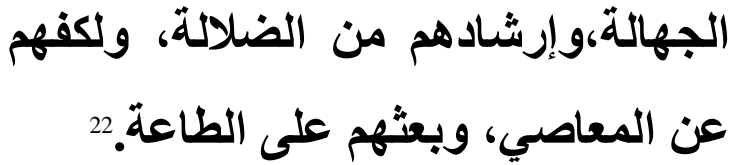

Tindak pidana (jarimah) dan ancaman hukumannya dimaksudkan untuk menjaga kemashlahatan, ketertiban, kekuatan, dan keluhuran budi pekerti masyarakat. Karena Allah Zat yang mensyariatkan hukum dan memerintahkan untuk mengikuti hukumhukum tersebut tidak akan terpengaruh oleh kemaksiatan dan ketaatan manusia, bahkan selalu melimpahkan rahmat kepada hamba-Nya dan seorang Rasul tidak akan diutus, melainkan menjadi rahmat bagi alam semesta dan menghindari umat manusia dari kejahiliyahan, serta menunjukan sinar terang dari kegelapan dan mencegah dari kemaksiatan serta mendorong untuk berlaku taat. ${ }^{23}$

Tujuan hukum pidana Islam merupakan gabungan antara teori pembalasan (teori absolut) dan tujuan preventif (teori relatif), yaitu bentuk pencegahan agar kejahatan dapat ditekan lebih dini. Maksud utama hukuman adalah memelihara dan menciptakan kemashlahatan manusia dan menjaga dari hal-hal yang mafsadat karena Islam sebagai rahmatan lil al'alamin memberi petunjuk dan pelajaran kepda manusia. ${ }^{24}$

\section{Tindak Pidana PelakuEksploitasi Seksual Pada Anak Menurut Hukum Islam}

${ }^{22}$ Abdul Qadir Audah, Al-Tasyri' Al-Jinai Al-Islami: Muqaranan bi Al-Qanun Al-Wad'I,, h. 69-70.

${ }^{23}$ Musthofa Hasan, Hukum Pidana Islam: Fiqh Jinayah, h. 28.

${ }^{24}$ Ibid., h. 29. 
1. Pengertian eksploitasi seksual pada anak

Islam merupakan aturan agama untuk menjamin, melindungi dan menjaga kemashlahatan umat manusia, baik berupa perintah atau larangan yang bersifat mengikat dan harus dipatuhi oleh umatnya.Dalam hal tertentu, aturan tersebut sudah disertai ancaman dunia disertai dengan ancaman akhirat apabila dilanggar. $^{25}$ Pengertian seksualitas didefinisikan secara luas sebagai suatu keinginan untuk menjalin kontak, kehangatan, kemesraan atau mencintai. ${ }^{26}$ Eksploitasi seksual merupakan suatu tindakan perbuatan yang menuju pada arah asusila.Karena didalamnya terdapat unsur yang bersifat negatif terhadap pengaruh seksual.

Anak adalah amanat Allah SWT yang harus senantiasa dipelihara.Apapun statusnya, pada dirinya melekat harkat, martabat, dan hak-hak sebagai manusia yang harus dijunjung tinggi.Namun, pada kenyataannya betapa banyak anak yang terlantar, tidak mendapatkan pendidikan karena tidak mampu, bahkan menjadi

25 Sayyid Sabiq, Fiqih Sunnah 10, terj. Moh Thalib,(Bandung: PT. Al-Ma'arif, 1987), h. 10 .

${ }^{26}$ Faridah Thalib, Kekerasan Seksual Dalam Rumah Tangga Tinjauan Hukum Islam Terhadap UU No. 23 Tahun 2004 Tentang Pengahapusan Kekerasan Dalam Rumah Tangga, (Banjarmasin, Antasari Press, 2009), cet ke-1, h. 9. korban tindak kekerasan. Hidupnya tidak menentu, masa depan tidak jelas dan rentan terhadap berbagai upaya eksploitasi oleh oknum-oknum yang tidak bertanggungjawab. $^{27}$ Sebagai orangtua yang merasa mendapat amanat seharusnya mereka akan berusaha sekuat tenaga untuk menjaga dan memelihara anak-anak dengan memberikan pendidikan yang sebaik-baiknya, mengikuti perkembangan demi perkembangan baik fisik maupun kejiwaannya, dan tidak membiarkan mereka salah langkah dalam melewati masa-masa pertumbuhannya, karena sekali salah langkah maka hal itu akan memberi pengaruh yang besar bagi kehidupan masa depannya. $^{28}$

Salah satu perasaan mulia yang Allah tanamkan di dalam hati kedua orangtua adalah rasa kasih sayang kepada anak-anak.Perasaan yang mulia di dalam mendidik anak dan mempersiapkan mereka memperoleh hasil yang terbaik dan pengaruh yang besar.Orangtua yang tidak memiliki kasih sayang akan membuahkan perilaku-perilaku menyimpang pada anakanak, kebodohan dan kesusahan. ${ }^{29}$ Islam juga mengatur tentang pentingnya menjaga

${ }^{27}$ Djaenab, Perlindungan Anak Perspektif Fiqh dan Perundang-undangan, dalam jurnal Arrisalah, no 1, vol 10 (2010): h. 3.

${ }^{28}$ Juwairiyah, Dasar-dasar Pendidikan Anak Dalam Al-Qur'an, (Yogyakarta: Teras, 2010), h. 73 .

${ }^{29}$ Abdullah Nashih 'Ulwan, Tarbiyatul Aulad fil Islam, terj. Arif Rahman hakim dan Abdul Halim,(Solo: Insan Kamil, 2012), h. 23. 
serta memelihara hak dan kehormatan anak dengan baik agar mendapat perlindungan dari hal-hal yang dapat merusak masa depannya kelak. Adapun hak-hak yang harus diperoleh anak dalam Islam untuk menjaga martabat dan kehormatan anak yaitu, diantaranya:

1) Mendapatkan tuntunan akhlak serta penanaman akidah yang benar

2) Mendapatkan nafkah yang halal, pendidikan,pengajaran yang baik

3) Mendapat perlindungan dari segala gangguan dan tindakan yang dapat merusak masa depan anak.

Ajaran Islam sangat menekankan perlindungan terhadap anak serta kasih sayang orangtua, sebagaimana yang dijelaskan dalam hadits Nabi Muhammad SAW: ${ }^{30}$

Artinya:"Diriwayatkan Umar bin Hafs, meriwayatkan kepada kami ayahku, meriwayatkan kepada kami al-A'masy, dia berkata: meriwayatkan kepadaku Zaid bin Wahab, dia berkata: mendengar Jarir bin Abdullah dari Nabi SAW, bersabda:"Seseorang yang tidak mempunyai rasa kasih sayang, maka ia

\footnotetext{
${ }^{30}$ Muhammad bin Ismail alBukhari,Shohih al-Bukhari, Bab Rohmatin-Naas wa al-Bahaim, (Damaskus: Dar al-Kutub alIlmiyah, 2008), juz 2, no. Hadis 6013, h. 103.
}

tidak akan dikasihi sayangi." (HR. AlBukhari)

Allah SWT telah menciptakan manusia dengan segenap potensi, berupa akal maupun kebutuhan-kebutuhan naluri.Di antara naluri yang diberikan adalah naluri untuk melestarikan jenis.Salah satu bentuknya adalah rasa suka terhadap lawan jenis.Nafsu syahwat atau naluri menjadi sesuatu yang alami dan naluriah dalam diri manusia. Berkaitan dengan potensi naluri seksual pada manusia, Islam tidak melarang manusia untuk bersenang-senang.Namun, Islam menentukan batasan-batasan yang dibolehkan.Dengan demikian, Islam tidak membiarkan seseorang mengambil kesenangan di bawah penderitaan orang lain, sebagai tindakan eksploitasi seksual terhadap anak.Eksploitasi seksual merupakan tindakan yang tercela karena Islam menjamin kehormatan setiap individu (termasuk anak-anak).

Tindakan eksploitasi seksual tidak pernah dikenal dalam Islam. Istilah yang dikenal dalam hukum Islam hanyalah tindak perzinahan dan praktik pelacuran yang dilakukan terhadap budak-budak wanita pada zaman Nabi Muhammad SAW.

2. Bentuk dan unsur tindakan eksploitasi seksual 
Dalam Islam tidak menyebutkan secara jelas pengertian serta pembahasan secara khusus tentang tindakan eksploitasi seksual terhadap anak.

Berkaitan dengan bentuk hubungan seksual diluar perkawinan, Islam hanyamengatur tindakan perzinahan dan kasus pelacuran terhadap budak-budak wanita yang dilakukan oleh tuannya, agar tuannyadapat mengambil upah dari perbuatan tersebut. Terdapat ayat-ayat AlQur'an dan hadits NabiSAW yang berbicara tentang tindakan pelacuran terhadap budak wanita, yaitu: (Q.S. AnNur/24:33) $)^{31}$

\section{Asbabun nuzul ayat:}

Dari Jabir, ia berkata Abdullah bin Ubay ibn Salul berkata kepada budak perempuannya yang bernama Masikah, "Pergi dan melacurlah untuk kami."Dan ketika ayat tentang zina turun, budak tersebut berkata, 'Demi Allah, saya tidak akan pernah berzina selamanya.'Lalu Allah SWT menurunkan ayat,“...dan janganlah kamu paksa budak-budak perempuanmu untuk melakukan pelacuran, sedang mereka sendiri menginginkan kesucian ...,32

Dalam tafsir lain dijelaskan: Diriwayatkan oleh Muslim dan Abu Daud dari Ja>birbahwa Abdullah bin Ubay

\footnotetext{
${ }^{31}$ Departemen Agama R.I, Al-Qur'an dan terjemahnya, h. 549.

${ }^{32} \mathrm{Abu}$ Nizhan, Al-Qur'an Tematis, (Bandung: Mizan, 2011), h. 514.
}

mempunyai dua hamba sahaya perempuan, yaitu Musaikah dan Umaimah. Lalu ia memaksanya untuk melacur, kemudian mereka mengadukan hal ini kepada Rasulullah SAW, maka turunlah ayat ini. ${ }^{33}$

Diriwayatkan oleh Ibn Mardawaih dari Ali bahwa orang-orang Arab pada zaman jahiliyah memaksa budak-budaknya melacurkan diri untuk mendapatkan uang, maka hal itu dilarang dalam Islam dengan dasar ayat ini, adapun untuk budak-budak yang dipaksa untuk berzina, maka ia tidak dikenakan hukuman berdasarkan ayat:

\section{Artinya:"Barangsiapa}

yang memaksa mereka, Maka Sesungguhnya Allah adalah Maha Pengampun lagi Maha Penyayang (kepada mereka) sesudah mereka dipaksa itu”

$$
\text { Perempuan-perempuan yang }
$$
dipaksa melacur akan diampuni dosanya oleh Allah, dan dosa itu dipikul oleh yang memaksanya. Hasan al-Bishri tiap membaca ayat ini mengatakan:'Bagi perempuan-perempuan itu", yaitu yang dipaksa melacurkan diri, Allah mengampuni dan merahmatinya. ${ }^{34}$

Penjelasan ayat:

Kata "al-bigha> "yang diambil dari kata "bagha>"yang antara lain berarti

\footnotetext{
${ }^{33}$ Departemen Agama R.I, Al-Qur'an dan Tafsirnya, (Jakarta: Lentera Abadi, 2010), h. 602.

${ }^{34}$ Teungku Muhammad Hasbi ashShiddieqy, Tafsir Al-Qur'an Majid An-Nuur, (Semarang: Pustaka Rizku Putra, 2000), h. 2823.
} 
“melampaui batas.”Jika pelaku ini seorang perempuan, ini menunjukan sebagai perempuan yang profesinya adalah perzinaan.Sebagai profesi tentu saja terjadi berkali-kali serta disertai dengan imbalan materi.Perempuan yang melakukannya dinamakan“baghiyyah"(wanita pelacur). ${ }^{35}$

Dalam tafsir Jalalain dijelaskan: (wa la> tukrihu fa ta ya>tikum) "Dan janganlah kamu memaksa pemudipeтudimu", maksudnya budak-budak perempuanmu ('alal bigha) "untuk menjadi pelacur”, yakni berbuat zina, (in aradna takhas\}uhunan) "Sedang mereka sendiri menghendaki kesucian”, maksudnya menjaga diri dari perbuatan zina, keinginan inilah yang menjadi letak pemaksaan itu, (litab’taghu>)“Karena kamu ingin mendapatkan" melalui pemaksaan itu ( 'aradha $>$ lhaya $>$ tid\} unya >) "Keuntungan duniawi". 36

As-Suddi berkata, "Ayat yang mulia ini turun kepada Abdullah bin Ubay bin Salul, pemimpin orang-orang munafik. Dia memiliki budak wanita bernama Mu'adzah. Bila seorang bertamu kepadanya, dia menyuruhnya agar

\footnotetext{
${ }^{35}$ M.Quraish Shihab, Tafsir Al-Mishbah; pesan, kesan dan keserasian Al-Qur'an, (Jakarta: Lentera Hati, 2002), h. 540.

${ }^{36}$ Al-Imam Jalaluddin Muhammad bin Ahmad bin Muhammad Al-Mahalli, Al-Imam Jalaluddin Abdirrahman bin Abu Bakar AsSuyuthi, Tafsir Jalalain, terj. Najib Junaidi, (Surabaya: Pustaka eLBA, 2010), h. 610.
}

melayani tamu berzina untuk mendapatkan imbalan darinya dan untuk menghormati tamu itu. Maka, mengadulah budak wanita tersebut kepada Abu Bakar Ash-Shiddiq ra. Perihal itu. kemudian Abu Bakar juga mengadukannya kepada Rasulullah. Maka, beliaupun menyuruhnya untuk menahan budak itu. lalu, berserulah Abdullah bin Ubay bin Salul dengan lantang, "siapa yang menghalangi kami dari Muhammad? Dia telah bertindak terlalu jauh dalam mengatur budak-budak kita" maka Allahpun menurunkan ayat ini kepada mereka. $^{37}$

Ibn Arabi mengutip dari riwayat Imam Malik dan az-Zuhri yang menyatakan bahwa seorang tawanan perang badr ditahan pada Abdullah Ibn Ubay Ibn Salul. Tawanan ini hendak berhubungan seks dengan Mu'adzah, salah seorang dari budak wanita yang dipekerjakan 'Abdullah sebagai pelacur itu.Tetapi Mu'adzah enggan karena ia telah memeluk Islam, namun 'Abdullah memaksa dan memukulnya, dengan harapan wanita itu hamil dari sang tawanan, lalu ia menuntut ganti rugi. Karena kebiasaan masyarakat jahiliyah adalah membayar kepada tuan pemilik hamba sahaya seratus ekor unta untuk

${ }^{37}$ Sayyid Quthb, Tafsir fi Zhilalil-Qur'an: di Bawah Naungan Al-Qur'an, terj. As'ad Yasin, dkk. (Jakarta: Gema Insani, 2004), h. 239 
membayar anaknya yang lahir dari sang pelacur milik tuan itu. Menurut riwayat tadi, Mu'adzah datang mengadu kepada Nabi SAW, dan turunlah ayat ini. ${ }^{38}$

Riwayat lain menyatakan bahwa 'Abdullah Ibn Ubay memang menyediakan "wanita-wanita penghibur" untuk menghormati tamu-tamunya. Salah seorang di antara mereka adalah Mu'adzah. Saat itu tiba saatnya Mu'adzah mengadu kepada Sayyidina Abu Bakar ra. Dan melaporkan hal tersebut kepada Nabi SAW. Nabi kemudian memerintahkan Abu Bakar menangkap Abdullah bin Ubay,ayat ini turun berkenan dengan kasus itu. ${ }^{39}$ Pada masa Jahiliah dikenal empat macam cara untuk menjalin hubungan seksual. Pertama, cara yang dikenal hingga kini, yaitu melamar seorang wanita kepada walinya, membayar mahar, dan dinikahkan. Kedua, mengirim istri yang telah suci dari haidnya untuk "tidur" bersama seorang pria yang dipilih dan setelah jelas bahwa ia mengandung barulah ia kembali ke suaminya. Tujuan cara ini adalah memperoleh anak dari seorang yang dinilai memiliki benih unggul. Ketiga, berkumpul dalam satu grup yang jumlahnya kurang dari sepuluh orang lalu mereka berhubungan dengan seorang wanita, dan bila hamil dan

\footnotetext{
${ }^{38}$ M.Quraish Shihab, Tafsir Al-Mishbah; pesan, kesan dan keserasian Al-Qur'an,h. 541.

${ }^{39}$ Ibid.
}

melahirkan dia memanggil seluruh anggota grup tanpa seorangpun yang dapat mengelak dan mengingatkan mereka tentang hubungan mereka dengannya. Lalu, wanita itu menunjuk salah seorang yang dipilihnya untuk menjadi ayah anaknya dan diberi nama dengan nama yang dinisbahkan kepada siapa yang terpilih itu. Yang keempat, adalah "albigha $>$ (perzinahan, pelacuran). Kemudian Islam datang menghapus semua bentuk itu kecuali yang pertama. ${ }^{40}$

Nabi MuhammadSAW melarang dengan tegas untuk mengambil upah atau bayaran dari pelacur, Nabi SAW bersabda:

Artinya:"Dari Abu Mas'ud Al Anshary, sesungguhnya Rasulullah SAW melarang (memanfaatkan) hasil penjualan anjing, hasil pelacuran dan upah dukun."(HR. Bukhari) ${ }^{41}$

Didalam hadis lain juga disebutkan, Artinya:"Musa bin Ismail mengabarkan kepada kami, mengabarkan kepada kami Aban dari yahya, dari Ibrahim bin Abdillah Ya'ni bin Qariz, dari Sa'ib bin yazid, dari Rofi' bin Khodij bahwa Rasulullah SAW, bersabda: "Penghasilan tukang bekam itu tercela, harga anjing itu tercela, dan

\footnotetext{
${ }^{40}$ Ibid., h. 542.

${ }^{41}$ Abu Abdullah Muhammad bin Ismail alBukhari, Ensiklopedi Hadis Shahih Bukhari 1, terj. Mahsyar, (Jakarta: al-Mahira, 2011), h. 495.
} 
bayaran wanita pelacur juga tercela." (HR. Abu Daud $)^{42}$

Dalam ayat dan kedua hadits tersebut di atas disebutkan dengan jelas tentang larangan untuk menjerumuskan seseorang dalam tindakan pelacuran dan juga mengambil upah dari usaha pelacuran tersebut.Karena tindakan pelacuran merupakan sebuah pekerjaan yang dilarang dalam Islam.Didalamnya mengandung unsur bahaya bagi masyarakat, baik terhadap akidahnya dan sendi-sendi sopan santun.

Pelacuran merupakan salah satu mata pencaharian yang dibolehkan di negara-negara Barat dengan diberinya izin dengan syarat si pelakunya harus memberikan jaminan kepada si pemilik kedai itu dan memberikan hak-hak mereka.Begitulah situasi ini pernah berlaku pada zaman dahulu sampai datanglah Islam untuk menghapus itu semua. $^{43}$ Sebagian orang jahiliyah ada yang menetapkan upah pekerjaan harian hamba perempuannya dan hasilnya supaya diserahkan kepada tuannya dengan jalan apapun. Seringkali menjurus kepada perbuatan zina supaya dia dapat membayar apa yang telah ditetapkan atas dirinya itu.

\footnotetext{
${ }^{42}$ Abu Daud Sulaiman bin al-Asy'ats Jastani, Ensiklopedi Hadis 5 Sunan Abu Daud, terj. Muhammad Ghazali, dkk. (Jakarta: al-Mahira, 2013), h. 727. Islam, h. 182.
}

Bahkan sebagian mereka ada yang sampai memaksa hamba sahayanya untuk melacur semata-mata untuk mencari keuntungan duniawi yang rendah dengan pekerjaan yang terlarang itu. $^{44}$ Unsur tindakan eksploitasi seksual itu sendiri tidak terdapat secara jelas dan rinci dalam Islam, namun jika dipahami dan dicermati berdasarkan penjelasan ayat QS. AnNur/24:33 dan hadis Nabi tentang larangan melacurkan budak-budak wanita yang dilakukan oleh tuannya, serta melarang mengambil upah (keuntungan) dari wanita pelacur. Maka dapat diketahui bahwa unsur-unsur tindak eksploitasi seksual yang dalam hukum Islam disebut dengan tindakan pelacuran ialah:

1) Adanya perempuan-perempuan yang dilacurkan, yang dalam hal ini yaitu para budak-budak wanita.

2) Adanya pelaku yang menyuruh atau memaksa perempuan untuk melakukan pelacuran, yaitu tuan-tuan (majikan) mereka.

3) Adanya niat dan keinginan pelaku untuk mengambil keuntungan atau upah dari perbuatan tersebut.

Tindakan pelacuran mengandung banyak mudharat yang tidak diragukan

\footnotetext{
${ }^{44}$ Ibid., h. 183
} 
lagi. Ia merupakan faktor utama penyebab kerusakan moralitas. Selain itu, ia dapat menjadi penyebab tersebarnya berbagai jenis penyakit dan mendorong laki-laki untuk tetap membujang, dan lebih senang berpacaran. Karena itu, ia merupakan faktor utama terjadinya kerusakan, tindakan yang melampaui batas, tersebarnya prostitusi, serta timbulnya beragam tindak kriminal. $^{45}$ Prostitusi merupakan suatu profesi yang dibolehkan di negara-negara barat. Bahkan di sana memberikan izin bagi kegiatan prostitusi, serta menganggap pelakunya termasuk orang-orang yang bekerja seperti yang lainnyadan memberi hak-hak mereka. Sebaliknya, Islam menolak dengan keras semua kegiatan prostitusi ini, serta melarang wanita-wanita merdeka dan juga budak-budak wanita untuk mencari nafkah dari melacur. ${ }^{46}$

Dengan demikian, Nabi melarang mencari nafkah dengan usaha yang kotor ini betapapun tingginya bayaran yang diperoleh, walau dengan dorongan apapun (seperti dorongan ekonomi). Dan menjauhi sebisa mungkin agar jangan sampaidikatakan bahwa pekerjaan ini sudah menjadisuatu kebutuhan atau karena keadaan yang darurat atau karena tujuan-

\footnotetext{
${ }^{45}$ Sayyid Sabiq, Fiqih Sunhah, terj. Abdurrahim dan Masukhin, (Jakarta: Cakrawala Publising), h. 231.

${ }^{46}$ Yusuf Al-Qaradhawi, Halal Haram Dalam Islam. Terj. Abu Hana Zulkarnain, (Jakarta: AKBAR, 2004), h.177.
}

tujuan tertentu. Sehingga masyarakat Islam tetap bersih dari tindakan yang sangat membahayakan ini. $^{47}$ Islam tidaklah mengharamkan suatu pekerjaan kecuali didalamnya terdapat kezaliman, penipuan, penindasan. Maka hal tersebut sangat dilarang oleh Islam. Karena setiap usaha yang datang melalui jalan yang diharamkan tersebut merupakan suatu dosa. $^{48}$

Oleh karena itu, semua tindakan yang dapat membangkitkan hawa nafsu seseorang, maka hal itu dapat dikatakan sebagai perbuatan yang mendekati zina. Hal tersebut dapat dikaitkan dengan tindakan pelaku eksploitasi seksual pada anak yakni yang dilakukan oleh seorang perantara (mucikari, germo) yang hal tersebut dapat membuka jalan kepada suatu hubungan yang diharamkan oleh Islam.

3. Sanksi hukuman

Dalam hukum pidana Islam tindakan eksploitasi seksual ini merupakan suatu bentuk jarimah yang berkaitan dengan kejahatan kehormatan dan kerusakan akhlak.

Jarimah mengandung arti perbuatan buruk, jelek atau dosa. Jarimah biasa dipakai sebagai perbuatan dosa, bentuk, macam atau sifat dari perbuatan

\footnotetext{
${ }^{47}$ Ibid., h. 178.

${ }^{48}$ Ibid., h. 187.
} 
dosa tersebut. Misalnya pencurian, pembunuhan, perkosaan atau perbuatan yang berkaitan dengan politik dan sebagainya. Jarimah identik dengan pengertian yang disebut dalam hukum positif sebagai tindak pidana atau pelanggaran. Dalam hukum positif jarimah diistilahkan dengan delik atau tindak pidana. $^{49}$

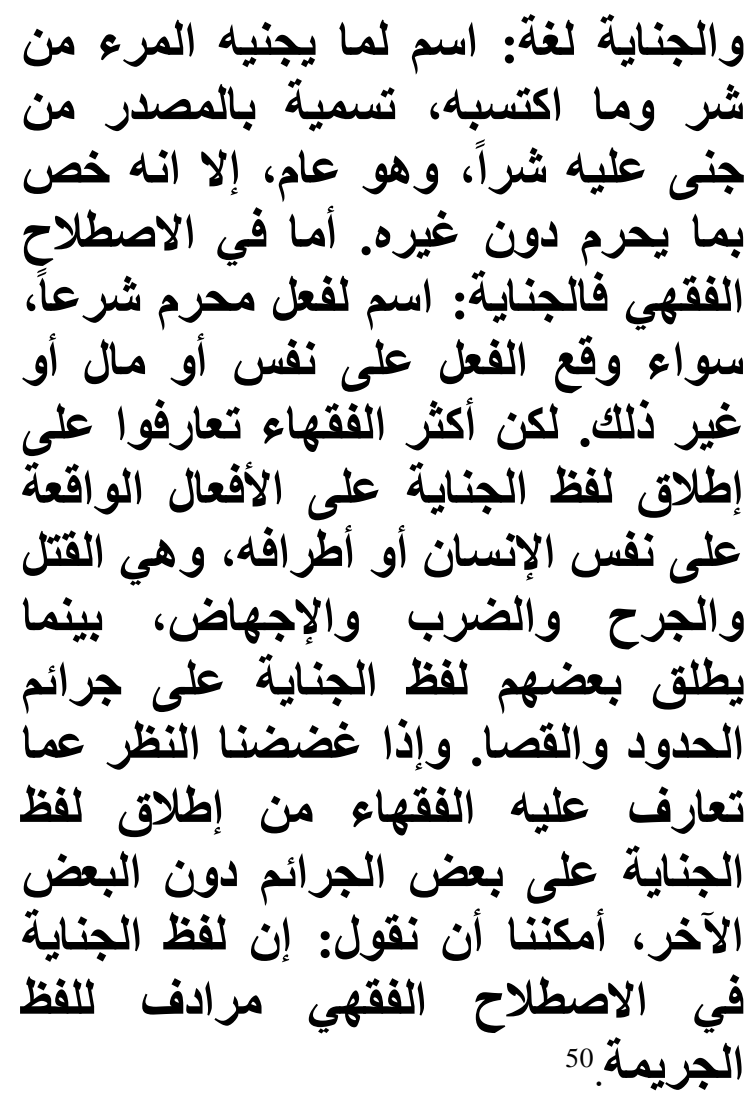

Dari uraian di atas dapat dipahami bahwa jinayah secara terminologi dipahami sebagai sebutan bagi setiap tindakan negatif yang dilakukan seseorang. Secara termonologi, jinayah diartikan

${ }^{49}$ Rahmat Hakim, Hukum Pidana Islam:Fiqh Jinayah, (Bandung: Pustaka Setia, 2009), h. 14-15.

${ }^{50}$ Abdul QadirAudah, Al-Tasyri' Al-Jinai Al-Islami: Muqaranan bi Al-Qanun Al-Wad'I, (Beirut: Muassasah Al-Risalah, 1987), h. 67 sebagai istilah operasional bagi setiap tindakan yang dilarang atau diharamkan atas seseorang, harta benda, dan lainnya. Jadi, jinayah adalah setiap tindakan negatif yang menimpa jiwa menusia atau anggota dabannya, misalnya pembunuhan, perampokan, dan lainnya.

Istilah lain dari jinayah adalah jarimah yang berarti segala larangan yang diancam oleh Allah dengan sanksi hukum yang ditentukan (had) atau yang tidak ditentukan. Arti dari "segala larangan" dapat berupa perbuatan aktif melakukan tindakan yang diperintahkan. Hal ini menunjukan bahwa istilah jinayah secara operasional identik dengan istilah jarimah yang mengandung pengertian tindakan yang dilarang dan diancam oleh hukum. ${ }^{51}$

Dasar hukum tindak pidana eksploitasi seksual terhadap anak ditinjau dari hukum Islam dapat dikategorikan dengan tindakanpelacuran.Islam menentukan dengan sangat jelas bahwa kejahatan tersebut merupakan kejahatan yang sangat bahaya, karena menyangkut harkat dan martabat manusia. Unsur penting dalam hukum Islam yang perlu diketahui adalah perbuatan melanggar hukum yang lazim disebut dengan jarimah dan ancaman hukuman yang lazim disebut uqubah.Jarimah secara etimologis adalah

${ }^{51}$ MusthofaHasan, HukumPidana Islam: FiqhJinayah, (Bandung: CV PustakaSetia, 2013), h. 16. 
semua perbuatan atau tindakan pidana yang mengandung unsur dosa, baik besar maupun kecil. ${ }^{52}$

Dalam hukum pidana Islam secara jelas tidak menemukan bentuk pidana atau jarimah terhadap perilaku tindakan eksploitasi seksual pada anak, karena hal tersebut merupakan sebuah kasus yang baru, belum terjadi pada zaman Nabi, akan tetapi terdapat beberapa ayat Al-Qur'an dan hadis Nabi yang memang tidak langsung berkaitan dengan eksploitasi, namun ada kemiripan yakni ayat dan hadis yang berbicara masalah tindakan pelacuran yang terjadi pada zaman Nabi dahulu, yaitu tindakan pelacuran yang dilakukan oleh Abdullah bin Ubay bin Salul terhadap budak-budak wanitanya. Beratnya ancaman pidana dalam Islam diiringi aturan-aturan yang menghindari manusia dari dorongan nafsu seksual yang bebas, dan mendorong umatnya untuk melakukan perkawinan sebagai jalan yang sah untuk melakukan hubungan seksual. Karena salah satu prinsip yang ditetapkan dalam Islam adalah bahwa jika Islam melarang suatu perbuatan, maka ia juga melarang segala macam perantara yang mengarah pada sesuatu yang dilarang itu dan menutup jalan menuju kearah yang dilarang tersebut. Berdasarkan konsep saddudz dzara-i', yaitu bahwa Allah

\footnotetext{
${ }^{52}$ H.A. Djazuli, Fiqih Jinayat, (Jakarta: PT. Grafindo Persada, 1996), h.121.
}

melarang sesuatu berarti juga melarang mengerjakan sesuatu yang menjadi jalan menuju sesuatu yang dilarang itu. Begitu juga Allah menyuruh sesuatu berarti juga menyuruh mengerjakan jalan (sarana) yang dapat menyampaikan kepada sesuatu yang disuruh itu, artinya jalan-jalan yang akan melancarkan terjadinya kerusakan wajib dihindarkan. ${ }^{53}$

Untuk menetapkan hukum jalan (sarana) yang menghantarkan kepada tujuan, perlu diperhatikan:

a) Tujuan (maqasid), jika tujuannya dilarang, maka hukum wasilah (sarana) nya dilarang. Jika tujuannya diwajibkan, maka hukum wasilahnya diwajibkan.

b) Niat (motif) yang mendorong seseorang berbuatn sesuatu. Jika niatnya untuk mencapai yang halal, maka hukum sarananya halal. Jika niatnya untuk mencapai yang haram, maka hukum saranya adalah haram.

c) Akibat dari suatu perbuatan, dalam hal ini hukum tidak bisa ditetapkan dengan pertimbangan niat saja, tetapi diperhatikan juga akibat dari

\footnotetext{
${ }^{53}$ Syarmin Syukur, Sumber-Sumber
} Hukum Islam,(Surabaya: Al-Ikhlas, 1993), h.246. 
perbuatan itu. jika perbuatan itu menghasilkan kemashlahatan, maka wasilah hukumnya boleh dikerjakan. Dan sebaliknya, jika perbuatan itu mengakibatkan kerusakan, meskipun tujuannya baik, maka wasilah dihukum tidak boleh dikerjakan. ${ }^{54}$

Adapun mengenai ketentuan sanksi terhadap perbuatan eksploitasi seksual yang dilakukan pada anak. Dalam hukum Islam, ketentuan tindakan eksploitasi seksual initidak dikenal, tetapi tindak eksploitasi seksual ini dikategorikan sebagai kejahatan seks. Unsur-unsur tindak pidana eksploitasi seksual pada anak tidak dijelaskan secara rinci. Mengingat tindakan eksploitasi seksual ini memilik dampak yang tidak sejalan dengan tuntunan syari'at yakni tidak boleh membuat bahaya terhadap orang lain ataupun bagi dirinya. Sebagaimana sabda Nabi SAW:

\section{Artinya: "Tidak boleh membuat}

\section{kemudharatan kepada diri sendiri dan}

tidak boleh pula membuat membuat

kemudharatan pada orang lain". 55

Dalam hal ini, menetapkan sanksi hukum dalam kasus eksploitasi seksual pada anak, bukanlah memberikan sanksi

\footnotetext{
${ }^{54}$ Ibid., h. 247.

${ }^{55}$ Dahlan Tamrin, Kaidah-kaidah Hukum Islam; Kulliyah Al-Khamsah, (Malang: UIN-Maliki Press, 2010), h. 153.
}

pada pelaku yang berhubungan dengan anak. Tapi menentukan sanksi terhadap pelaku eksploitasi, perantara (germo, mucikari) yang memanfaatkan tubuh anak untuk dieksploitasi agar mendapat keuntungan dari tindakan tersebut. Sesuai dengan jenis-jenis jarimah dan sanksinya, maka tindak pidana eksploitasi seksual termasuk dalam jarimah ta'zir.Hukuman jarimah ta'zirtidak ditentukan ukuran atau kadarnya, artinya untuk menentukan batas terendah dan tertinggi diserahkan sepenuhnya kepada hakim (penguasa). Dengan demikian, syari'ah menyerahkan kepada hakim untuk menentukan bentukbentuk dan hukuman kepada pelaku jarimah ${ }^{56}$

Hukuman ta'zir menurut terminologi fiqih Islam ialah merupakan tindakan edukatif terhadap pelaku perbuatan dosa yang tidak ada sanksi dan kifaratnya. Dengan kata lain, ta'zir adalah hukuman yang bersifat edukatif yang ditentukan oleh hakim atas pelaku tindak pidana atau kepastian hukumnya belum ada. Hukuman ta'zir itu bisa dilakukan dengan peringatan, penghinaan, pukulan, kurungan penjara, pengasingan, dan lainlain. ${ }^{57}$ Jarimah ta'zirialah suatu jarimah yang hukumannya diserahkan kepada hakim atau penguasa. Hakim dalam hal ini

\footnotetext{
${ }^{56}$ Makhrus Munajat, Dekonstruksi Hukum, (Jakarta: Radja Grafindo Persada, 2004), h. 13

${ }^{57}$ Sayyid Sabiq, Fikih Sunnah 10, terj. Moh. Thalib, h. 154-155.
} 
diberi wewenang untuk menjatuhkan hukuman bagi pelaku jarimah ta'zir. ${ }^{58}$ Pemberian kekuasaan dalam menentukan bentuk jarimah ini kepada penguasa agar mereka merasa leluasa mengatur pemerintahan sesuai dengan situasi dan kondisi wilayahnya, serta kemashlahatan daerahnya. Oleh karena itu, jarimah ta'zir sering disebut dengan jarimah kemashlahatan umum. Mengenai hukuman (sanksi), syara' hanya menyebutkan bentuk-bentuk hukuman dari yang berat sampai yang ringan. Tanpa mengharuskan hukuman tertentu untuk jarimah yang tertentu pula. Dalam menangani jarimah ini, hakim diberikan keleluasaan untuk menentukan vonis kepada pembuat jarimah, sesuai dengan jenis jarimah dan keadaan pelakunya. ${ }^{59}$

Ciri-ciri yang mutlak yang terdapat pada jarimah ta'zir adalah:

1) Setiap jarimah tidak memerlukan ketentuan khusus,

2) Bentuk perbuatan yang dapat merugikan orang lain

3) Ketentuan hukumnya menjadi wewenang hakim

4) Jenis sanksinya bervariasi

Penerapan dan pemberlakuan hukuman syara' bisa memberikan efek jera, sehingga ia tidak berani untuk

\footnotetext{
${ }^{58}$ Makhrus Munajat, Hukum Pidana Islam di Indonesia, h. 178.

${ }^{59}$ MusthofaHasan, HukumPidana Islam: FiqhJinayah, h. 75.
}

mengulangi kejahatannya lagi. Di antara tujuan hukuman, memperbaiki dan merehabilitasi jiwa, meluruskan pandangan dan kesadaran, meyakinkan dan menyadarkan terpidana akan kesalahannya, serta melindungi masyarakat dari tabiat-tabiat yang buruk. ${ }^{60}$

\section{Analisis Perbandingan Tindak}

\section{Pidana Eksploitasi Seksual Pada}

\section{Anak Menurut Hukum Islam dan}

\section{Hukum Positif}

\section{Analisis berdasarkan pengertian}

Islam merupakan aturan agama untuk menjamin, melindungi dan menjaga kemashlahatan umat manusia, baik berupa perintah atau larangan yang bersifat mengikat dan harus dipatuhi oleh umatnya.Dalam hal tertentu, aturan tersebut sudah disertai ancaman dunia disertai dengan ancaman akhirat apabila dilanggar. ${ }^{61}$

Di dalam Islam tidak menyebutkan secara khusus pengertian serta pembahasan secara khusus tentang tindakan eksploitasi seksual terhadap anak.

Tindakan eksploitasi seksual tidak pernah dikenal dalam Islam. Istilah yang dikenal dalam hukum pidana Islam hanyalah tindakan pelacuran yang

${ }^{60}$ Wahbah Az-Zuhaili, Fiqih Islam Wa Adillatuhu jilid 7, terj. Abdul Hayyie al-Kattani, dkk.(Jakarta: Gema Insani, 2011), h. 271.

${ }^{61}$ Sayyid Sabiq, Fiqih Sunnah 10, terj. Moh Thalib, h.10 
dilakukan oleh para majikan terhadap budak-budak wanita pada zaman Nabi Muhammad SAW. Agar tuannya dapat mengambil upah dari perbuatan tersebut. Terdapat ayat-ayat Al-Qur'an dan hadits NabiSAW yang mengatur tentang tindakan pelacuran terhadap budak wanita, yaitu terdapat dalam Q.S. An-Nur/24:33: ${ }^{62}$

Jika diperhatikan susunan ayat tersebut, maka pertama-tama Allah SWT menyuruh kita untuk memelihara diri dari fitnah dan maksiat, yaitu dengan menundukan mata dari melihat bagian jenis tubuh yang terlarang. Sesudah itu Allah menyuruh kita menikah untuk memelihara agama dan berikutnya menyuruh kita menahan syahwat. Ayat ini memerintahkan kita untuk bersabar dalam menikah, jika memang belum mampu memberikan kebutuhan dalam rumah tangga. ${ }^{63}$

Kemudian Allah SWT mendorong kita, para mukmin agar menolong para budak untuk bisa memerdekakan diri, selain menyuruh para tuan (pemilik) budak yang bersangkutan memberikan sebagian hartanya kepada budak yang dimiliknya untuk dapat dipergunakan untuk membayar tebusan atas dirinya. ${ }^{64}$

\footnotetext{
${ }^{62}$ Departemen Agama R.I, Al-Qur'an dan Terjemahnya, h. 549.

${ }^{63}$ Teungku Muhammad Hasbi ashShiddieqy, Tafsir Al-Qur'anul Majid AnNur,(Semarang: Pustaka Rizki Putra, 2000), h. 2822.

$$
{ }^{64} \text { Ibid. }
$$
}

Pada penggalan ayat yang terakhir yaitu "Wa la> tukrihuu fa taya>atikum 'alal bi-ghaa-i in aradna tahas\}h-s\}hunal li tabta-ghuu 'ara-dhal hayaatiddun-ya”, janganlah kamu memaksa budak perempuanmu supaya mereka melacurkan diri untuk mencari kekayaan, sedangkan mereka sesungguhnya tidak mau melakukannya. Firman Allah SWT ini tidak memberi pengertian bahwa larangan memaksa mereka melacurkan diri adalah jika mereka tidak menyukainya. Sebenarnya, walaupun mereka menyukainya, tetap tidak boleh menyuruh mereka melacurkan diri. ${ }^{65}$ Pada ayat tersebut sangatlah jelas terdapat larangan untuk melakukan tindakan eksploitasi seksual terhadap para perempuan.

Adapun sebab turunnya ayat tersebut yaitu: Diriwayatkan oleh Muslim dan Abu Daud dari Jabir bahwa Abdullah bin Ubay mempunyai dua hamba sahaya perempuan, yaitu Musaikah dan Umaimah. Lalu ia memaksanya untuk melacur, kemudian mereka mengadukan hal ini kepada Rasulullah SAW, maka turunlah ayat ini. Demikian peraturan yang diturunkan Allah untuk keharmonisan dan kebersihan suatu masyarakat, bila dijalankan dengan sebaik-baiknya akan terciptalah masyarakat yang bersih, aman

\footnotetext{
${ }^{65}$ Ibid., h. 2823.
} 
dan bahagia jauh dari hal-hal yang membahayakan. ${ }^{66}$

Berbeda dengan pengertian eksploitasi seksual menurut hukum positif telah jelas diatur dalam Undang-Undang Republik Indonesia Nomor 21 Tahun 2007, Pasal 1 ayat (8) bahwa:

Eksploitasi seksual adalah segala bentuk pemanfaatan organ tubuh seksual atau organ tubuh lain dari korban untuk mendapatkan keuntungan, termasuk tetapi tidak terbatas pada semua kegiatan pelacuran dan pencabulan.

Eksploitasi seksual dapat pula diartikan dengan tindakan pelacuran dan prostitusi yang berarti praktik hubungan seksual sesaat, yang kurang lebih dilakukan dengan siapa saja, untuk imbalan berupa uang. Menurut Purnomo dan Siregar menjelaskan bahwa yang dimaksud dengan protitusi adalah peristiwa penyerahan tubuh oleh wanita kepada banyak lelaki dengan imbalan pembayaran guna disetubuhi dan sebagai pemuas nafsu seks si pembayar, yang dilakukan diluar pernikahan. ${ }^{67}$ Eksploitasi seksual komersial anak diartikan sebagai penggunaan anak untuk tujuan seksual dengan imbalan tunai atau dalam bentuk lain antara anak, pembeli jasa seks, perantara atau agen, dan pihak lain yang

\footnotetext{
${ }^{66}$ Departemen Agama R.I, Al-Qur'an dan Tafsirnya, h. 602. h. $159-160$.
}

memperoleh keuntungan dari perdagangan seksualitas anak tersebut. ${ }^{68}$

Dari kedua pengertian di atas terdapat perbedaan yang sangat signifikan dari kedua pandangan antara hukum Islam dan hukum positif tentang pengertian tindakan pelaku eksploitasi seksual pada anak.

Hukum Islam tidak menyebutkan secara jelas tentang pengertian eksploitasi seksual pada anak, karena di dalam ayat QS. An-Nur/24:33 hanya menyebutkan secara umum tentang larangan melacurkan budak-budak perempuan dan ayat tersebut didukung dengan hadits-hadits Nabi SAW mengenai larangan mengambil upah dari wanita pelacur.

2. Analisis berdasarkan bentuk dan unsur tindakan eksploitasi

Di dalam Islam tidak ada terdapat secara jelas pengertian serta pembahasan secara khusus tentang tindakan eksploitasi seksual terhadap anak, mengingat kasus ini merupakan kasus yang baru yang tidak pernah terjadi pada zaman Rasulullah SAW. Oleh karena itu bentuk eksploitasi seksualpun tidak diatur secara jelas dalam Islam. Seperti yang terdapat pada pembahasan sebelumnya bahwa jika dikaitkan dengan pengertian eksploitasi seksual, Islam hanya mengenal istilah pelacuran terhadap budak wanita. Seperti

${ }^{68}$ H.R. Abdussalam dan Adri Desasfuryanto, Hukum Perlindungan Anak, h. 1. 
yang terdapat dalam ayat QS. An-

Nur/24:33 yang menyebutkan secara umum tentang larangan melacurkan budak-budak perempuan dan ayat tersebut didukung dengan hadits-hadits Nabi SAW mengenai larangan mengambil upah dari wanita pelacur.

Ayat tersebut turun berkenaan dengan tindakan yang dilakukan oleh Abdullah bin Ubay ibn Salul yang mempunyai dua hamba sahaya perempuan yaitu Musaikah dan Umaimah. Lalu ia memaksanya untuk melacur, kemudian mereka mengadukan hal ini kepada Rasulullah SAW, maka turunlah ayat tersebut.

Sedangkan dalam hukum positif telah mengatur bentuk tindakan eksploitasi seksual pada anak, yaitupraktek prostitusi atau pelacuran anak yaitu penggunaan anak dalam kegiatan seksual dengan pembayaran atau dengan imbalan dalam bentuk lain. Prostitusi merupakan perilaku atau tindakan yang mengaitkan kegiatan seksual dengan uang. Prostitusi merupakan pekerjaan yang tidak membutuhkan keterampilan, banyak menyerap tenaga kerja, melibatkan perempuan dan berbayaran tinggi, bahkan dikalangan perempuan yang bekerja sebagai PSK (pekerja seks komersil) di jalanan sekalipun, bayaran mereka relatif lebih tinggi daripada pekerjaan lain yang berkeahlian di wilayah yang sama. ${ }^{69}$

Berdasarkan kedua pandangan di atas antara hukum Islam dan hukum positif, jika dipahami sebenarnya keduanya terdapat persamaan dalam aspek bentuk tindakan eksploitasi yaitu samasama mengartikannya dengan tindakan pelacuran. Namun, yang berbeda di sini yaitu dalam hukum Islam yang disebutkan dalam tindakan pelacuran adalah para budak-budak wanita pada zaman Nabi Muhammad SAW bukan pada anak-anak, untuk usia budak-budak wanita itu sendiri apakah telah mencapai usia dewasa atau masih anak-anak (belum baligh), hukum Islam tidak secara jelas menyebutkan. Badasarkan unsur-unsur tindakan eksploitasi seksual pada anak menurut pandangan hukum Islam dan hukum positif seperti yang telah dipaparkan pada pembahasan yang lalu yaitu:

Menurut hukum Islam, unsur tindakan eksploitasi seksual itu sendiri tidak terdapat secara jelas dan rinci dalam Islam, namun jika dipahami dan dicermati berdasarkan penjelasan QS. An-Nur/24:33 dan hadis Nabi tentang larangan melacurkan budak-budak wanita yang dilakukan oleh tuannya, serta hadis Nabi

\footnotetext{
${ }^{69}$ Bagong Suyanto, Anak Perempuan Yang Dilacurkan Korban Eksploitasi Seksual Komersial, h. 43.
} 
yang melarang mengambil upah dari wanita pelacur

Juga terdapat dalam hadits Nabi Muhammad SAW:

Artinya:"Dari Abu Mas'ud Al Anshary, sesungguhnya Rasulullah SAW melarang (memanfaatkan) hasil penjualan anjing, hasil pelacuran dan upah dukun."(HR. Bukhari) $)^{70}$

Berdasarkan ayat dan hadits di atas maka dapat ditarik bahwa unsur-unsur tindak eksploitasi seksual yang dalam hukum Islam disebut dengan tindakan pelacuran ialah:

1) Adanya budak-budak wanita yang dilacurkan. Berdasarkan lafaz ayat: "Dan janganlah kamu memaksa budak-budak wanitamu”, ('alal bigha>) “untuk melakukan pelacuran”.

2) Adanya pelaku yang menyuruh atau memaksa budak wanita untuk melakukan pelacuran. Berdasarkan asbabun nuzul ayat yaitu berkenaan dengan Abdullah bin Ubay ibn Salul yang memaksa budak-budak perempuannya untuk berzina (menjadi pelacur).

3) Adanya niat dan keinginan pelaku untuk mengambil

\footnotetext{
${ }^{70} \mathrm{Abu}$ Abdullah Muhamad bin Ismail AlBukhari, Ensiklopedi HadisShahih al-Bukhari 1, terj. Mahsyar, h. 495.
}

keuntungan atau upah dari perbuatan tersebut. Berdasarkan ayat: "karen kamu ingin mendapatkan keuntungan duniawi”.

Tindakan pelacuran mengandung banyak mudharat yang tidak diragukan lagi. Ia merupakan faktor utama penyebab kerusakan moralitas. Selain itu, ia dapat menjadi penyebab tersebarnya berbagai jenis penyakit dan mendorong laki-laki untuk tetap membujang, dan lebih senang berpacaran. Karena itu, ia merupakan utama terjadinya kerusakan, tindakan yang melampaui batas, tersebarnya prostitusi, serta timbulnya beragam tindak kriminal. ${ }^{71}$

Peneliti memahami di antara kedua unsur di atas menurut pandangan hukum Islam dan hukum positif, bahwa kedua unsur-unsur tersebut terdapat persamaan yaitu:

Pertama, adanya korban atau orang yang tereksploitasi yang dijerumuskan dalam tindakan pelacuran, dalam hal ini yaitu menurut hukum Islam adalah budakbudak wanita yang menjadi korban tindakan pelacuran oleh pemiliknya (tuannya). Sedangkan dalam hukum positif korban di sini yaitu anak yang tereksploitasi.

Kedua, adanya pelaku atau orang yang mengeksploitasi (pelaku kejahatan).

\footnotetext{
${ }^{71}$ Sayyid Sabiq, Fiqih Sunhah, terj.
} Abdurrahim dan Masrukhin, h. 231. 
Yakni pelaku melakukan perbuatan tindak pidana (pelaku jarimah) yang mampu dipertanggungjawaban secara hukum atas perbuatan pidana yang ia lakukan tersebut.

Ketiga, ada maksud niat dan tujuan untuk meguntungkan diri sendiri atau orang lain. Keuntungan berupa bayaran atau upah dari tindak pidana (jarimah) yang dilakukannya tersebut.

3. Analisis Berdasarkan Sanksi

\section{Hukuman}

Melihat sanksi hukum terhadap tindak pidana pelaku eksploitasi seksual pada anak menurut pandangan hukum Islam dan hukum positif memang tentu sangtlah berbeda. Hukum Islam tidak mengatur secara khusus sanksi hukuman bagi pelaku pelacursn terhadap budakbudak wanita.

Dalam hukum pidana Islam tindakan eksploitasi seksual ini merupakan suatu bentuk jarimah yang berkaitan dengan kejahatan kehormatan dan kerusakan akhlak. Sesuai dengan jenisjenis jarimah dan sanksinya, maka tindak pidana eksploitasi seksual termasuk dalam jarimah ta'zir. Hukuman jarimah ta'zir tidak ditentukan ukuran atau kadarnya, artinya untuk menentukan batas terendah dan tertinggi diserahkan sepenuhnya kepada hakim (penguasa). Dengan demikian, syari'ah menyerahkan kepada hakim untuk menentukan bentuk-bentuk dan hukuman kepada pelaku jarimah.$^{72}$

Seperti dalam riwayat yang menyatakan bahwa Abdullah Ibn Ubay menyediakan "wanita-wanita penghibur" untuk melayani tamu-tamunya. Salah seorang di antara mereka adalah Mu'adzah. Saat itu tiba saatnya Mu'adzah mengadu kepada Sayyidina Abu Bakar ra. Dan melaporkan hal tersebut kepada Nabi SAW. Nabi kemudian memerintahkan Abu Bakar menangkap Abdullah bin Ubayy. ${ }^{73}$

Berdasarkan riwayat di atas hukuman yang diberikan kepada Abdullah bin Ubay ibn Salul diserahkan kepada pemimpin yakni Rasulullah SAW, karena ia telah melacurkan budak-budak wanitanya. Karena hukumannya tidak ditentukan dengan tegas maka tindakan pelacuran tersebut masuk dalam kategori jarimah ta'z|iryang hukumannya diserahkan kepada hakim atau penguasa. Hakim dalam hal ini diberi wewenang untuk menjatuhkan hukuman bagi pelaku jarimah ta'zir. Hukuman ta'zir dijatuhkan dengan mempertimbangkan berat ringannya tindak pidana, situasi dan kondisi masyarakat, serta tuntunan kepentingan umum. Hal ini dapat dikatakan bahwa hukuman ta'zir diterapkan tidak secara definitif,

\footnotetext{
${ }^{72}$ Makhrus Munajat, Dekonstruksi Hukum, h. 13
} 
melainkan melihat situasi dan kondisi, dan bagaimana perbuatan jarimah terjadi, kapan waktunya, siapa korbannya, dan sanksi yang pantas dikenakan demi menjamin ketentraman dan kemashlahatan umat. $^{74}$

Adapun perempuan-perempuan yang dipaksa melacur akan diampuni dosanya oleh Allah SWT, seperti yang dikatakan oleh Hasan al-Bishri "bagi perempuan-perempuan itu, yaitu yang dipaksa melacurkan diri, Allah mengampuni dan merahmatinya".

Seandainya seorang laki-laki dipaksa untuk berzina lalu dia berzina, maka dia tidak dikenakan had. Begitu juga seorang perempuan, bila dia dipaksa berzina maka tidak dilaksanakan had baginya. Hal itu didasarkan pada sabda Rasulullah Saw.: Dari Ibn Abbas, (bahwa) Nabi Saw bersabda, "Sesungguhnya Allah menghapus (hukuman) bagi umatku (yang berbuat kesalahan karena) keliru, lupa, dan apa saja yang mereka kerjakan karena terpaksa". 75

Dari segi hukuman yang dapat dijatuhkan kepada pelaku. Dalam aspek tujuan hukuman, antara hukum Islam dan hukum positif bahwa sama-sama menyatakan bahwa hukuman bertujuan agar memberikan efek jera dan balasan

\footnotetext{
${ }^{74}$ Makhsrus Munajat, Hukum Pidana Islam di Indonesia, h.4.

${ }^{75}$ Sayyid Sabiq, Fiqih Sunah, terj. Moh. Thalib, h. 101-102
}

bagi pelaku tindak pidana eksploitasi seksual. Dan esensi hukuman yang mengangkat derajat manusia khususnya perempuan-perempuan dan anak-anak yang menjadi korban eksploitasi seksual berupa tindakan pelacuran.

E. Hukum pidana Islam merupakan bagian dari hukum Islam dan tujuan yang terkandung dalam hukum pidana Islam tidak terlepas dari tujuan hukum Islam. Hukum Islam bertujuan menciptakan kemashlahatan bagi kehidupan umat manusia, ik dunia maupun akhirat.

\section{PENUTUP}

\section{Simpulan}

Berdasarkan hasil penelitian yang penulis lakukan terhadap bahan-bahan hukum, baik itu dari bahan hukum Islam dan bahan-bahan hukum Positif. Maka penulis dapat menyimpulkan, bahwa: Tindak pidana eksploitasi seksual pada anak tidak diatur secara khusus dalam Islam. Dalam Islam hanya terdapat ayat dan hadis Nabi yang mengatur tentang larangan untuk melacurkan budak-budak perempuan serta larangan mengambil keuntungan dari hasil tindakan pelacuran. Sedangkan menurut hukum positif tindak pidana eksploitasi seksual pada anak tersebut diatur dalam UU No. 23 tahun 2002 Tentang Perlindungan Anak yaitu tindakan memanfaatkan tubuh anak untuk dijadikan pekerja seksual. 


\section{Saran}

Tindak pidana pelaku eksploitasi seksual anak dapat dianggap sebagai tindak pidana yang serius, oleh karena itu para pemerintah penegak hukum diharapkan untuk benar-benar menegakan dan menjatuhkan hukuman dengan tegas bagi para pelaku tindakan eksploitasi seksual pada anak. Tidak hanya peran pemerintah, namun masyarakat juga wajib berpartisipasi seperti melaporkan jika mengetahui terjadi tindakan eksploitasi seksual pada anak. Khususnya orangorang terdekat anak-anak yaitu keluarga. Untuk anak yang telah menjadi korban eksploitasi, maka diharapkan adanya usaha yang serius untuk memulihkan kondisi mental anak akibat terkena dampak fisik maupun psikis dari tindakan eksploitasi seksual tersebut.

\section{Daftar Pustaka:}

Abu Bakar As-Suyuthi, Tafsir Jalalain, terj. Najib Junaidi, (Surabaya: Pustaka eLBA, 2010). Abdullah Nashih 'Ulwan, Tarbiyatul Aulad fil Islam, terj. Arif Rahman hakim dan Abdul Halim,(Solo: Insan Kamil, 2012).

Abu Nizhan, Al-Qur'an Tematis, (Bandung: Mizan, 2011).

Abu Abdullah Muhammad bin Ismail al-Bukhari, Ensiklopedi Hadis Shahih Bukhari 1, terj. Mahsyar, (Jakarta: al-Mahira, 2011).

Abu Daud Sulaiman bin al-Asy'ats Jastani, Ensiklopedi Hadis 5 Sunan Abu Daud, terj. Muhammad Ghazali, dkk. (Jakarta: al-Mahira, 2013).

Ahmad Hanafi, Asas-asas Hukum Pidana Islam,(Jakarta: Bulan Bintang, 1993).

Abdul QadirAudah, Al-Tasyri' Al-Jinai Al-Islami: Muqaranan bi Al-Qanun Al-Wad'I, (Beirut: Muassasah Al-Risalah, 1987).

Dahlan Tamrin, Kaidah-kaidah Hukum Islam; Kulliyah Al-Khamsah, (Malang: UIN-Maliki Press, 2010).

Departemen Agama Republik Indonesia, Al-Qur'an Dan Terjemahnya, (Jakarta: CV. Toha Putra Semarang, 1989).

Departemen Agama R.I, Al-Qur'an dan Tafsirnya, (Jakarta: Lentera Abadi, 2010).

Djazuli, Fiqih Jinayat, (Jakarta: PT. Grafindo Persada, 1996).

Djaenab, Perlindungan Anak Perspektif Fiqh dan Perundang-undangan, dalam jurnal AlRisalah, volume 10 (2010).

Faridah Thalib, Kekerasan Seksual Dalam Rumah Tangga Tinjauan Hukum Islam Terhadap UU No. 23 Tahun 2004 Tentang Pengahapusan Kekerasan Dalam Rumah Tangga, (Banjarmasin, Antasari Press, 2009).

Hamdan Rajih, Cerdas Akal Cerdas Hati, (Yogyakarta: Diva Press, 2008).

Imam An-Nawawi, Syarah Shahih Muslim, (Jakarta: Darus Sunnah, 2011).

Juwariyah, Dasar-Dasar Pendidikan Anak Dalam Al-Qur'an, (Yogyakarta: Teras, 2010). Jalaluddin Muhammad bin Ahmad bin Muhammad Al-Mahalli, Al-Imam Jalaluddin Abdirrahman bin Juwairiyah, Dasar-dasar Pendidikan Anak Dalam Al-Qur'an, (Yogyakarta: Teras, 2010). 
Majda El Muhtaj, Dimensi Dimensi HAM Mengurai Hak Ekonomi dan Budaya, (Jakarta: Rajawali Pers, 2009).

Musthofa Hasan, Hukum Pidana Islam: Fiqh Jinayah, (Bandung: CV Pustaka Setia, 2013).

Makhsrus Munajat, Hukum Pidana Islam di Indonesia, (Yogyakarta: Teras, 2009).

Muhammad bin Ismail al-Bukhari,Shohih al-Bukhari, Bab Rohmatin-Naas wa al-Bahaim, (Damaskus: Dar al-Kutub al-Ilmiyah, 2008).

MusthofaHasan, HukumPidana Islam: FiqhJinayah, (Bandung: CV PustakaSetia, 2013).

Makhrus Munajat, Dekonstruksi Hukum, (Jakarta: Radja Grafindo Persada, 2004).

M.Quraish Shihab, Tafsir Al-Mishbah; pesan, kesan dan keserasian Al-Qur'an, (Jakarta: Lentera Hati, 2002).

Republik Indonesia, Undang-Undang R.I. Nomor 23 Tahun 2002 Tentang Perlindungan Anak, (Bandung: Citra Umbara, 2012).

Sayyid Sabiq, Fiqih Sunnah 10, terj. Moh Thalib,(Bandung: PT. Al-Ma'arif, 1987).

Sayyid Quthb, Tafsir fi Zhilalil-Qur'an: di Bawah Naungan Al-Qur'an, terj. As'ad Yasin, dkk. (Jakarta: Gema Insani, 2004).

Syarmin Syukur, Sumber-Sumber Hukum Islam,(Surabaya: Al-Ikhlas, 1993).

Sayyid Sabiq, Fiqih Sunhah, terj. Abdurrahim dan Masukhin, (Jakarta: Cakrawala Publising).

Teungku Muhammad Hasbi ash-Shiddieqy, Tafsir Al-Qur'an Majid An-Nuur, (Semarang: Pustaka Rizku Putra, 2000).

Wahbah Az-Zuhaili, Fiqih Islam Wa Adillatuhu jilid 7, terj. Abdul Hayyie al-Kattani, dkk.(Jakarta: Gema Insani, 2011).

Yusuf Qardhawi, Halal wal Haram fil Islam, (Bandung: Jabal, 2009).

Yusuf Al-Qaradhawi, Halal Haram Dalam Islam. Terj. Abu Hana Zulkarnain, (Jakarta: Akbar, 2004). 